\title{
The Corporate Governance of Australian Listed Construction Companies
}

Patrick Tait and Martin Loosemore (Faculty of the Built Environment, University of New South Wales, Australia)

\section{ABSTRACT}

This paper compares the compliance level of Australian Stock Exchange (ASX) listed construction and non-construction companies with the ASX Corporate Governance Council (CGC) recommendations on sound corporate governance. It also examines the difference in board characteristics between the two groups, paying particular attention to differences in board independence. It concludes that compared with the top 20 ASX listed non-construction companies, listed construction companies are less compliant overall particularly with regards to board structure, and have lower levels of independence both in terms of CEO/Chairperson duality, the ratio of executive to non-executive independent directors and independent membership of nomination, remuneration and audit committees. These conclusions are important because sound corporate governance has been associated with higher levels of organisational resilience derived from the reputational and financial benefits of greater transparency, market value, investor attractiveness and organisational performance.

Keywords: corporate governance, compliance, resilience, independence, Australian Stock Exchange.

\section{INTRODUCTION}

Du Plessis et al. (2005; p.6) defined corporate governance as "the process of controlling management and of balancing the interests of all internal stakeholders and other parties (external stakeholders, governments and local communities) who can be affected by the corporation's conduct in order to ensure responsible behaviour by corporations and to achieve the maximum level of efficiency and profitability for a corporation". There are three contemporary trends that have promoted concerns with corporate governance standards, namely: the recent wave of high profile corporate scandals, globalisation, and increased investor activism.

For example, in Australia, corporate collapses such as $\mathrm{HIH}$ and One.Tel have demonstrated the domestic ramifications of ineffective governance practices (among other things), while scandals like Enron and WorldCom in America have highlighted the global impact (Ingley and van der Walt, 2003; Donker and Zahir, 2008). According to ACCA (2008) these failures of corporate governance have been the principal cause of the current credit crisis. They have also resulted in unprecedented erosion of investor confidence in trust managers, corporate managers and regulatory authorities which permitted these problems to arise undisclosed (Robins, 2006; Martin, 2001; Donker and Zahir, 2008).

Globalisation has focused attention on governance because of associated increased competition for investment capital (Kiel and Nicholson, 2003). With the increasing risks associated with providing credit, institutional investors are comparing organisations as potential investment opportunities and corporate governance structures are being used as an important point of comparison (Kiel and Nicholson, 2003).

Increased shareholder activism regarding standards of corporate governance has grown as the proportion of institutional investors to individual investors has grown. For example, Brancato and Rabimov (2008) found that institutional investors now own $76.4 \%$ of US companies and Mallin (2006) found that the rate is $50 \%$ in Australia. New legal requirements for institutional investors to act as 'fiduciaries' rather than short-term speculators is replacing short-term market myopia with a culture of ownership and greater concern for governance practices which ensure long-term stability (Monks and Minow, 2004; Davis et al., 2006).

The Building and Construction industry, like every industry, is exposed to investment capital competition, globalisation, investor activism and risk. This means that sound corporate governance is of central importance to its economic, social and environmental performance. More broadly, sound governance in the construction industry is important to society because construction is a key developmental industry with widespread social economic and environmental responsibilities (van Wyk and Chege, 2004). The industry is charged with creating and maintaining the built environment, which consists of homes, workplaces, schools, hospitals and other public amenities as well as essential infrastructure such as roads, water and electricity and telecommunications essential for our day to day living (ABS, 2007). Furthermore, the industry's products account for $23 \%$ of total greenhouse gas emissions, it directly employs about 875,000 people, represents about $6 \%$ of GDP and invests about $\$ 158 \mathrm{bn}$ each year on new construction. In particular, the increasing trend for procurement of public services via public-private partnerships that place the delivery and management of critical public infrastructure and services in private company hands, has brought issues of sound corporate governance to the fore (PPP Forum, 2008). PPP projects such as the Sydney airport rail link, Sydney Harbour Tunnel and the recent $\$ 900 \mathrm{~m}$ redevelopment of the Royal Children's Hospital in Melbourne demonstrate the public significance of the projects being undertaken and the potential implications of poor governance (Chang et al., 2006).

Given the above, it is surprising that the issue of corporate governance in the construction industry has received little attention. One notable exception is the work of Chang et al. (2006) who investigated the relative compliance of UK listed construction companies with the disclosure requirements of the UK Combined Code compared with the top 50 companies listed in the UK. Their research determined that UK listed construction companies: (1) demonstrated lower levels of disclosure of corporate governance information than the top 50 group, (2) had lower levels of board independence based on the separation of the CEO and chairperson position and independence of directors, and (3) made less use of external consulting services for advice. They noted that the disparity between the construction group and the top 50 group was a concern which could potentially lead to adverse effects on the construction companies' performance. 
In the above context, the aim of this paper is to explore the compliance levels of Australian listed construction companies with the ASX Corporate Governance Council's guidelines (ASX, 2003) compared to the top 20 ASX listed non-construction companies. It will also examine the difference in board characteristics between the two groups, paying attention to the differences in board independence and discuss the potential implications in any differences that are discovered in both compliance and board characteristics.

\section{THE BOARD OF DIRECTORS}

Fundamental to the corporate governance structure of any organisation is the board of directors. This is the body, elected or appointed by the shareholders, to act on their behalf in directing and controlling the affairs of the organisation (Matheson, 2004). The board of directors must satisfy a range statutory, common law and fiduciary responsibilities to the shareholders, other stakeholders and the organisation itself (Lawler III et al., 2002). This includes ensuring compliance with all relevant legal and regulatory requirements and promoting organisational performance. The latter is achieved through advising the CEO in the formulation of strategy and direction, evaluating CEO and senior manager performance, the acquisition and allocation of key resources, setting policies that guide and constrain management action and organisational culture, ensuring systems are in place to manage risk effectively, and ensuring the continuous improvement of the organisation's performance through constant monitoring and supervising of executive management (Scherrer, 2003; Nadler, 2004).

Directors are elected to boards for their industry or general business experience and expertise that they are expected to bring to the organisation in the form of advice and guidance for the CEO and the other members of the executive management team (Colley et al., 2003). Despite considerable research into the performance implications of board composition, it seems the only conclusion to draw is that there is no 'best practice' when it comes to board composition (Ingley and van der Walt, 2003; Matheson, 2004). It is widely accepted that board size is a reflection of three key factors (Kiel and Nicholson, 2003): the size of the organisation (board size increases as organisation size increases); the type of organisation (listed organisations tend to have larger boards); and the organisational structure (as more diversified organisations require representation from a wider array of business units and regions).

The size of the board should be large enough to provide required skills and experience, yet small enough to ensure efficient interaction and director participation (Murphy and McIntyre, 2007).

Another issue of debate is the level of independence among directors that relates primarily to the ratio of inside (executive), versus outside (non-executive and independent non-executive) directors and the separation of the CEO and chairman roles (Murphy and McIntyre, 2007). Non-executive directors play two important roles for the board (Mallin, 2007): to control and balance the executive directors power, making sure that no one individual has too much influence over board decisions, and to provide important external contribution to the general leadership and development of the organisation. Recent changes in corporate governance regulations around the world, promoting greater independence, represent contemporary thought that majority independent boards result in higher corporate performance than executive-dominated boards (Van den Berghe and Baelden, 2005). However, the evidence is conflicting as it is in the case of whether the two roles of CEO and chairman should be separated (Khanchel, 2007).

\section{CORPORATE GOVERNANCE REGULATIONS}

In response to the corporate scandals of the 1990s, many countries produced guides to best practice in corporate governance. In the UK, the Combined Code (2003) emerged out of the Cadbury, Greenbury and Hampel reports and in the US, the Sarbanes-Oxley Act (2002) and revised NYSE listing requirements promoted stricter standards of corporate governance (NYSE, 2008; du Plessis et al., 2005). In Australia, the ASX Corporate Governance Council produced the Principles of Good Governance and Best Practice Recommendations (2003), implemented amendments to the Corporations Act (2001), and introduced the Corporate Law Economic Reform Program (Audit Reform and Corporate Disclosure) Act - CLERP 9 (2004) - which is essentially the Australian version of the Sarbanes-Oxley Act, strengthening the requirements of financial auditing (Robins, 2006). The ASX recommendations lay down ten core principles of good corporate governance (see Table 1) that are required to be demonstrated in annual reports. If not demonstrated companies are required to explain why.

\section{METHOD}

To compare the compliance level of ASX listed construction and non-construction companies with the ASX Corporate Governance Council Principles of Good Governance and Best Practice Recommendations (2003), a documentary analysis of qualitative and quantitative data in annual reports published by a sample of the top 20 ASX listed construction and non-construction companies was undertaken (see Table 2), based on market capitalisation, following the Chang et al. (2006) method. Construction companies were classified as those with 'construction' mentioned in the 'principal activities' section of their annual report. As part of its listing rules, the ASX requires that all listed organisations submit a Corporate Governance section in their annual reports that details their compliance with the ASX Principles and Recommendations along with an 'if not, why not' explanation for non-compliance with any of the recommendations. This section of the annual report was the basis of the documentary analysis supplemented by data from other parts of the report where necessary. For example, all annual reports included a section on the board of directors, detailing the number of directors, their independence and the presence of committees.

\section{RESULTS}

The companies' compliance with the recommendations was recorded, as in Chang et al. (2006), using a system of "0" representing non-compliance and " 1 " meaning compliance. An average was then taken across the entire sample to get an overall mean score. Table 3 is a summary of the results which shows that the overall mean level of compliance for construction companies is lower (28.25) than for non-construction companies (29.75). The areas of difference are illustrated in Figure 1, which shows that in general construction firms are comparable in corporate governance compliance to the top 20 ASX regarding Principles 1, 3, 5, 6, 8 and 10. In contrast, construction firms are less complaint regarding Principles 2, 4, 7 and 9.

Table 4 shows the summary of the board characteristics by comparing the average results of the two sample groups using the 0,1 scoring system explained above. Once again the level of overall compliance is lower in the construction sample.

The size of the board of the top 20 ASX listed non-construction companies ranged from 7 to 15 with an average number of 10.30 directors. This is compared to an average of 7.30 directors 


\begin{tabular}{|c|c|c|}
\hline Principle & Expla & Ination \\
\hline $\begin{array}{l}\text { 1. Lay solid } \\
\text { foundations for } \\
\text { management } \\
\text { and oversight }\end{array}$ & 1.1 & $\begin{array}{l}\text { Formalise and disclose the functions reserved to the board and those delegated to } \\
\text { management }\end{array}$ \\
\hline $\begin{array}{l}\text { 2. Structure the } \\
\text { board to add } \\
\text { value }\end{array}$ & $\begin{array}{l}2.1 \\
2.2 \\
2.3 \\
2.4 \\
2.5\end{array}$ & $\begin{array}{l}\text { A majority of the board should be independent directors } \\
\text { The chairperson should be an independent director } \\
\text { The roles of chairperson and chief executive officer should not be exercised by the same } \\
\text { individual } \\
\text { The board should establish a nomination which should have a minimum of } 3 \text { (majority } \\
\text { independent) directors, chaired by the board chairperson or an independent director } \\
\text { Provide details of the directors and their other appointments and reasons for non- } \\
\text { compliance with any of the recommendations }\end{array}$ \\
\hline $\begin{array}{l}\text { 3. Promote ethical } \\
\text { and responsible } \\
\text { decision } \\
\text { making }\end{array}$ & $\begin{array}{l}3.1 \\
3.1 .1 \\
3.1 .2 \\
3.2 \\
3.3\end{array}$ & $\begin{array}{l}\text { Establish a code of conduct to guide the directors, the chief executive officer (or } \\
\text { equivalent), the chief financial officer (or equivalent) and any other key executives as to: } \\
\text { the practices necessary to maintain confidence in the company's integrity } \\
\text { the responsibility and accountability of individuals for reporting and investigating reports of } \\
\text { unethical practices. } \\
\text { Disclose the policy concerning trading in company securities by directors, officers and } \\
\text { employees } \\
\text { Provide information relating to the company's ethical requirements }\end{array}$ \\
\hline $\begin{array}{l}\text { 4. Safeguard } \\
\text { integrity in } \\
\text { financial } \\
\text { reporting }\end{array}$ & $\begin{array}{l}4.2 \\
4.3\end{array}$ & $\begin{array}{l}\text { Require the chief executive officer (or equivalent) and the chief financial officer (or } \\
\text { equivalent) to state in writing to the board that the company's financial reports present a } \\
\text { true and fair view, in all material respects, of the company's financial condition and } \\
\text { operational results and are in accordance with relevant accounting standards } \\
\text { The board should establish an audit committee } \\
\text { Structure the audit committee so that it consists of: only non-executive directors, a majority } \\
\text { of independent directors, and an independent chairperson, who is not chairperson of the } \\
\text { board, at least three members. (Best practice would be only independent directors who } \\
\text { are all financially literate, with at least one director with financial experience and one with } \\
\text { industry knowledge) } \\
\text { The audit committee should have a formal charter } \\
\text { Provide information about the company's financial control systems to shareholders and } \\
\text { the public }\end{array}$ \\
\hline $\begin{array}{l}\text { 5. Make timely } \\
\text { and balanced } \\
\text { disclosure }\end{array}$ & 5.1 & $\begin{array}{l}\text { Establish written policies and procedures designed to ensure compliance with ASX Listing } \\
\text { Rule disclosure requirements and to ensure accountability at a senior management level } \\
\text { for that compliance } \\
\text { Provide information required by disclosure rules }\end{array}$ \\
\hline $\begin{array}{l}\text { 6. Respect the } \\
\text { rights of } \\
\text { shareholders }\end{array}$ & $\begin{array}{l}6.1 \\
6.2\end{array}$ & $\begin{array}{l}\text { Design and disclose a communications strategy to promote effective communication with } \\
\text { shareholders and encourage effective participation at general meetings } \\
\text { Request the external auditor to attend the annual general meeting and be available to } \\
\text { answer shareholder questions about the conduct of the audit and the preparation and } \\
\text { content of the auditor's report }\end{array}$ \\
\hline $\begin{array}{l}\text { 7. Recognise and } \\
\text { manage risk }\end{array}$ & $\begin{array}{l}7.1 \\
7.2 \\
7.2 .1 \\
7.2 .2 \\
7.3\end{array}$ & $\begin{array}{l}\text { The board or appropriate board committee should establish policies on risk oversight and } \\
\text { management. } \\
\text { The chief executive officer (or equivalent) and the chief financial officer (or equivalent) } \\
\text { should state to the board in writing that: } \\
\text { the statement given in accordance with best practice recommendation } 4.1 \text { (the integrity of } \\
\text { financial statements) is founded on a sound system of risk control which implements the } \\
\text { policies adopted by the board. } \\
\text { the company's risk management and internal compliance and control system is operating } \\
\text { efficiently and effectively in all material respects } \\
\text { Provide information about risk management policies and systems }\end{array}$ \\
\hline $\begin{array}{l}\text { 8. Encourage } \\
\text { enhanced } \\
\text { performance }\end{array}$ & 8.1 & $\begin{array}{l}\text { Disclose the process for performance evaluation of the board, its committees and } \\
\text { individual directors, and key executives }\end{array}$ \\
\hline $\begin{array}{l}\text { 9. Remunerate } \\
\text { fairly and } \\
\text { responsibly }\end{array}$ & $\begin{array}{l}9.1 \\
9.2 \\
9.3 \\
9.4 \\
9.5\end{array}$ & $\begin{array}{l}\text { Provide disclosure in relation to the company's remuneration policies } \\
\text { The board should establish a remuneration Committee consisting of a minimum of } 3 \\
\text { (majority independent) directors and be chaired by an independent director. } \\
\text { Clearly distinguish the structure of non-executive directors' remuneration from that of } \\
\text { executives; non-executives should not be offered retirement packages or performance } \\
\text { bonuses. } \\
\text { Ensure that payment of equity-based executive remuneration is made in accordance with } \\
\text { thresholds set in plans approved by shareholders } \\
\text { Provide information about the remuneration of executive and non-executive directors }\end{array}$ \\
\hline $\begin{array}{l}\text { 10. Recognise the } \\
\text { legitimate } \\
\text { interests of } \\
\text { shareholders }\end{array}$ & 10.1 & $\begin{array}{l}\text { Establish and disclose a code of conduct to guide compliance with legal and other } \\
\text { obligations to legitimate stakeholders such as clients/customers and the community in } \\
\text { which it operates }\end{array}$ \\
\hline
\end{tabular}


Table 2: Sample structure: ASX listed non-construction and construction companies

\begin{tabular}{|c|c|c|c|c|c|}
\hline \multicolumn{3}{|c|}{ Top 20 Listed ASX } & \multicolumn{3}{|c|}{ Listed Construction } \\
\hline Company & Employees & $\begin{array}{c}\text { Turnover } \\
(\$ \mathrm{~m})\end{array}$ & Company & Employees & $\begin{array}{c}\text { Turnover } \\
(\$ \mathrm{~m})\end{array}$ \\
\hline AMP Bank (AMP) & 4,000 & $11,018.00$ & AJ Lucas & 500 & 216.40 \\
\hline ANZ Bank (ANZ) & 34,353 & $11,385.00$ & AV Jennings & 450 & 632.20 \\
\hline BHP Billiton (BHP) & 39,000 & $47,473.00$ & Becton & 247 & 259.60 \\
\hline Brambles (BXB) & 12,305 & $3,868.80$ & $\begin{array}{l}\text { Bovis Lend } \\
\text { Lease }\end{array}$ & 12,039 & $14,282.00$ \\
\hline $\begin{array}{l}\text { Commonwealth } \\
\text { Bank (CBA) }\end{array}$ & 37,873 & $33,169.00$ & CEC Group & 500 & 143.40 \\
\hline CSL Limited (CSL) & 8,423 & $3,310.00$ & Clough & 4,000 & 761.20 \\
\hline $\begin{array}{l}\text { Fosters Group } \\
\text { (FGL) }\end{array}$ & 6,588 & $4,555.20$ & Devine & 229 & 547.97 \\
\hline $\begin{array}{l}\text { Macquarie Bank } \\
\text { (MQG) }\end{array}$ & 13,000 & $14,833.00$ & Diploma & 34 & 52.97 \\
\hline $\begin{array}{l}\text { National Aus. Bank } \\
\text { (NAB) }\end{array}$ & 43,000 & $44,448.00$ & Folkestone & $\mathrm{N} / \mathrm{A}$ & 81.04 \\
\hline $\begin{array}{l}\text { QBE Insurance } \\
\text { (QBE) }\end{array}$ & 10,600 & $14,966.00$ & Forge & 200 & 74.00 \\
\hline Rio Tinto (RIO) & 32,000 & $33,518.00$ & Leighton & 30,000 & $11,891.50$ \\
\hline $\begin{array}{l}\text { St George Bank } \\
\text { (SGB) }\end{array}$ & 8,074 & $3,272.00$ & Macmahon & 3,000 & 966.00 \\
\hline Stockland (SGP) & 1,241 & $3,300.00$ & Mirvac & $\mathrm{N} / \mathrm{A}$ & $2,220.90$ \\
\hline Suncorp (SUN) & 16,319 & $7,545.00$ & Stockland & 1,241 & $3,300.00$ \\
\hline Telstra (TLS) & 35,706 & $23,960.00$ & Sunland & $\mathrm{N} / \mathrm{A}$ & 634.27 \\
\hline $\begin{array}{l}\text { Westpac Bank } \\
\text { (WBC) }\end{array}$ & 28,000 & $25,935.00$ & $\begin{array}{l}\text { Thomas \& } \\
\text { Coffey }\end{array}$ & 1,000 & 219.00 \\
\hline Westfield (WDC) & 4,974 & $6,663.50$ & United & 29,000 & $3,500.00$ \\
\hline Wesfarmers (WES) & 30,000 & $9,754.00$ & VDM Group & 900 & 232.11 \\
\hline $\begin{array}{l}\text { Woolworths } \\
\text { (WOW) }\end{array}$ & 180,000 & $42,586.80$ & Watpac & 319 & 644.85 \\
\hline $\begin{array}{l}\text { Woodside } \\
\text { Petroleum (WPL) }\end{array}$ & 2,981 & $4,000.00$ & Westfield & 4,974 & $6,663.50$ \\
\hline
\end{tabular}

Table 3: Compliance with the ASX CGC recommendations

\begin{tabular}{|c|c|c|}
\hline & ASX Top 20 & Construction \\
\hline 1.1 & 1.00 & 1.00 \\
\hline 2.1 & 1.00 & 0.55 \\
\hline 2.2 & 0.85 & 0.80 \\
\hline 2.3 & 0.95 & 0.85 \\
\hline 2.4 & 1.00 & 0.70 \\
\hline 2.5 & 1.00 & 1.00 \\
\hline 3.1 & & \\
\hline 3.1 .1 & 1.00 & 1.00 \\
\hline 3.1 .2 & 1.00 & 1.00 \\
\hline 3.2 & 1.00 & 1.00 \\
\hline 3.3 & 1.00 & 1.00 \\
\hline 4.1 & 1.00 & 1.00 \\
\hline 4.2 & 1.00 & 1.00 \\
\hline 4.3 & 1.00 & 0.75 \\
\hline 4.4 & 1.00 & 1.00 \\
\hline 4.5 & 1.00 & 1.00 \\
\hline 5.1 & 1.00 & 1.00 \\
\hline 5.2 & 1.00 & 1.00 \\
\hline 6.1 & 1.00 & 1.00 \\
\hline 6.2 & 1.00 & 0.95 \\
\hline 7.1 & 1.00 & 0.95 \\
\hline 7.2 & & \\
\hline 7.2 .1 & 1.00 & 0.95 \\
\hline 7.2 .2 & 1.00 & 0.95 \\
\hline 7.3 & 1.00 & 1.00 \\
\hline 8.1 & 1.00 & 1.00 \\
\hline 9.1 & 1.00 & 1.00 \\
\hline 9.2 & 1.00 & 0.90 \\
\hline 9.3 & 1.00 & 1.00 \\
\hline 9.4 & 0.95 & 0.90 \\
\hline 9.5 & 1.00 & 1.00 \\
\hline 10.1 & 1.00 & 1.00 \\
\hline Aggregate Score & 29.75 & 28.25 \\
\hline
\end{tabular}




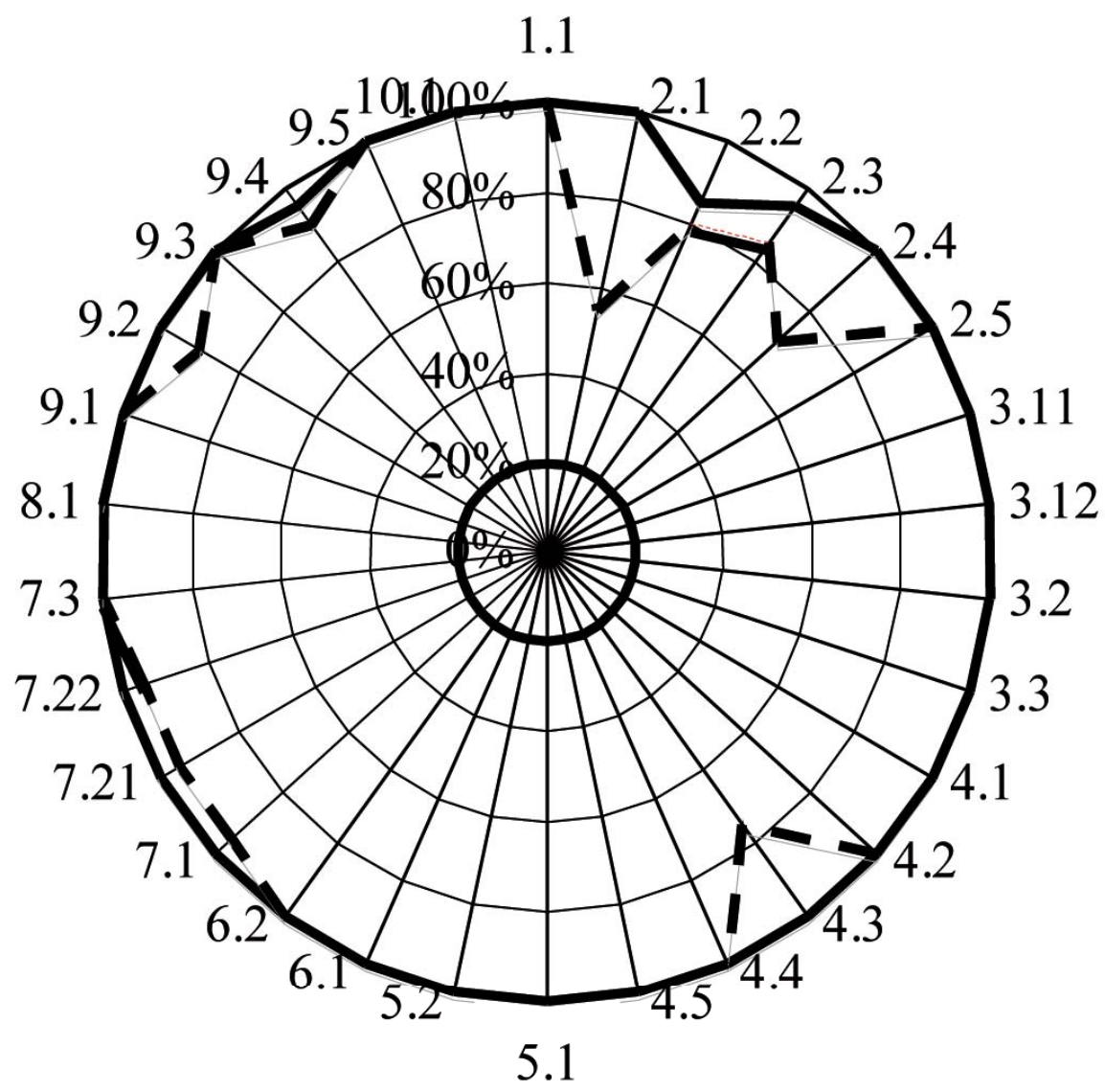

ASX Top 20

Construction

Table 4: Comparisons of average results for characteristics of the board of directors and board committees between ASX Top 20 and construction

\begin{tabular}{|c|c|c|}
\hline & ASX Top 20 & Construction \\
\hline Board Composition & \multirow[b]{2}{*}{0.95} & \multirow{2}{*}{ 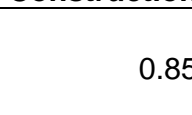 } \\
\hline $\begin{array}{l}\text { Are Chairman and CEO separated? } \\
\text { ("0" for "No"; "1" for "Yes") }\end{array}$ & & \\
\hline No. of Directors & \multirow{2}{*}{$\begin{array}{r}10.30 \\
1.80\end{array}$} & 7.30 \\
\hline No. Exec Directors (inc. chairman) & & 2.10 \\
\hline No. Non-Executive Directors & 8.50 & 5.15 \\
\hline $\begin{array}{l}\text { No. Non-Executives considered } \\
\text { Independent }\end{array}$ & \multirow[t]{2}{*}{8.15} & \multirow[t]{2}{*}{4.40} \\
\hline Nomination Committee & & \\
\hline No. Directors & \multirow{2}{*}{$\begin{array}{l}5.15 \\
4.95\end{array}$} & \multirow{2}{*}{$\begin{array}{l}4.15 \\
3.15\end{array}$} \\
\hline No. Non-Executive Directors & & \\
\hline Remuneration Committee & & \multirow{3}{*}{$\begin{array}{l}3.80 \\
3.05\end{array}$} \\
\hline No. Directors & & \\
\hline No. Non-Executive Directors & & \\
\hline Audit Committee & \multirow{3}{*}{$\begin{array}{l}4.50 \\
4.50\end{array}$} & \multirow{3}{*}{$\begin{array}{l}3.25 \\
3.00\end{array}$} \\
\hline No. Directors & & \\
\hline No. Non-Executive Directors & & \\
\hline Aggregate score & 56.30 & 40.20 \\
\hline
\end{tabular}


on construction boards, ranging from 3 directors up to 13 . A comparison between the two groups' board sizes is illustrated in Figure 2.

In terms of independence, the ratio of executive to non executive directors was on average $82.5 \%$ for the top 20 ASX listed companies and $70.5 \%$ for construction. The top 20 ASX listed companies' non-executive directors were almost all considered independent, with $96 \%$ meeting the ASX CGC independence guidelines whereas $85.4 \%$ met this standard in the construction group. These results give an overall independence level (independent directors to non-independent directors, according to the ASX CGC guidelines) of $79 \%$ for the top 20 non-construction group and $60 \%$ for the construction group. This is illustrated in Figure 3.

The important factor when looking at the various board committees required by the ASX guidelines is the levels of independence. The

Figure 2: Comparison of board sizes

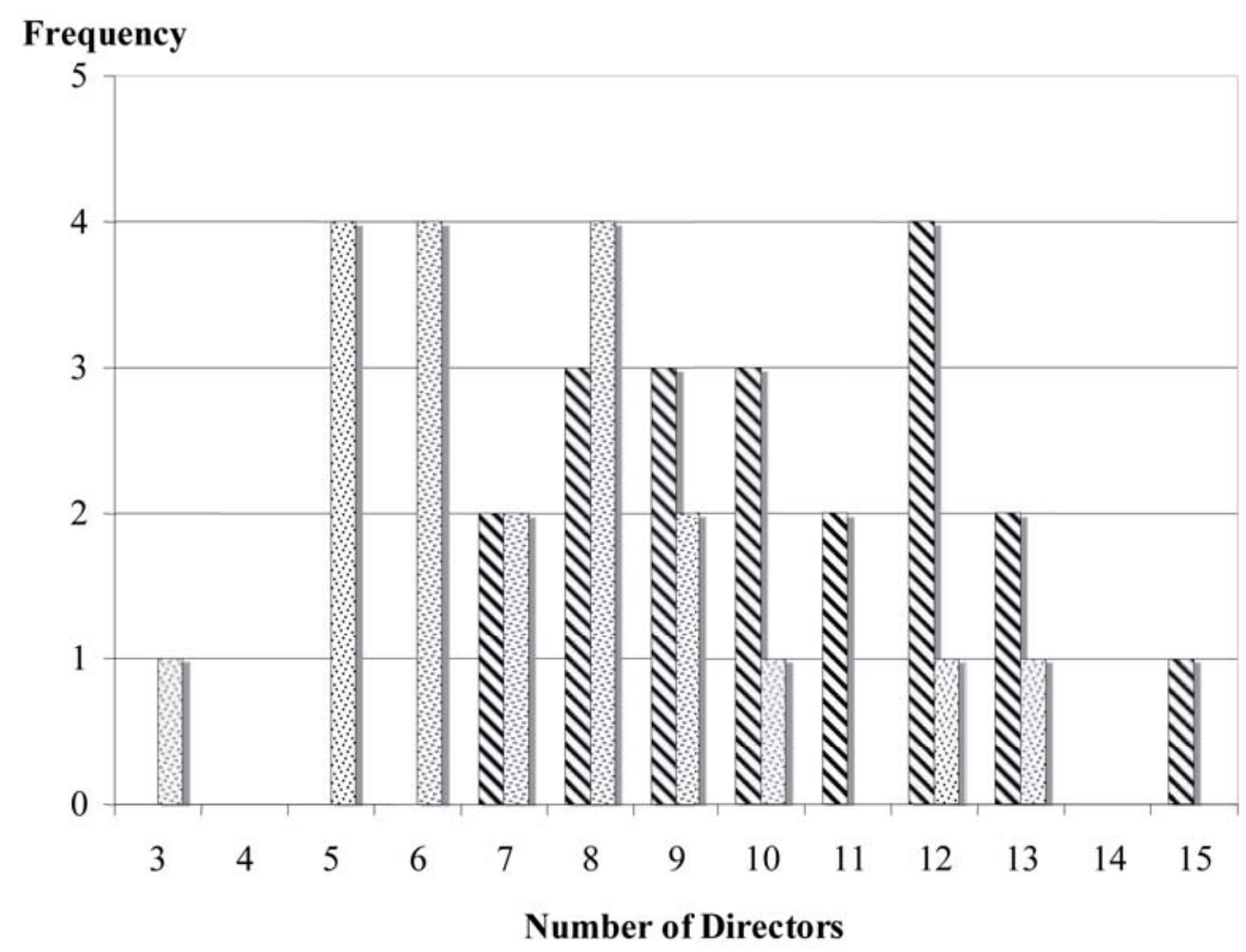

NASX Top 20圆 Construction

Figure 3: Independence levels

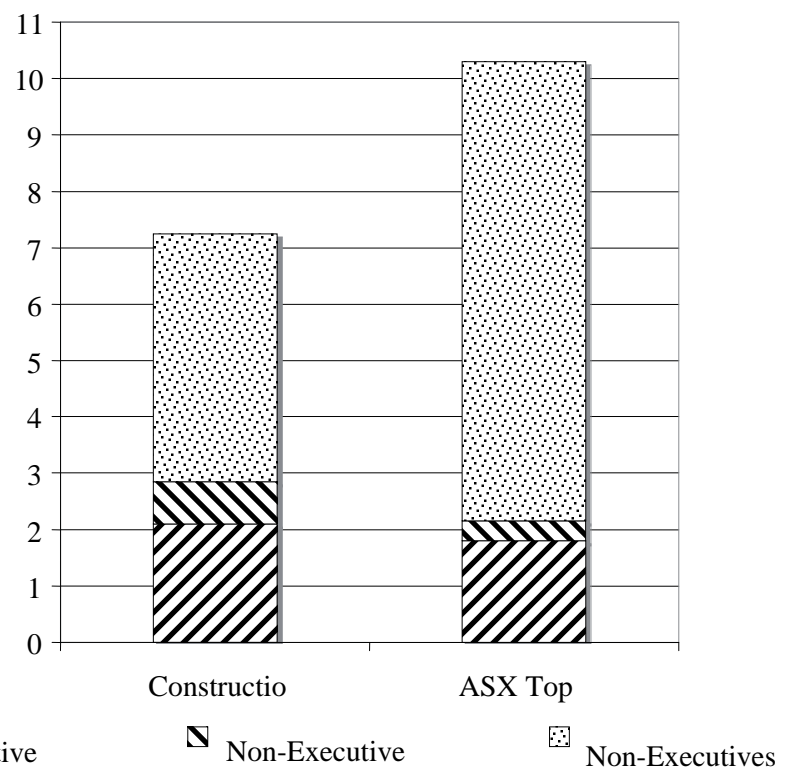


average size of the nomination committees in the top 20 ASX listed companies was 5.15 members, of which $96 \%$ were independent compared to construction that were smaller and less independent with an average of 4.15 members, of which $76 \%$ were independent directors. Seven construction companies had their whole boards acting as the nomination committee, which contrasts with the ASX guidance which recommends a separate nomination committee within a minimum of 3 (majority independent) directors, chaired by the board chairperson or an independent director.

The top 20 ASX listed companies recorded a 100\% independence score for their remuneration committees, whose average size was 3.75 directors. The listed construction companies had a slightly higher average membership of 3.80 with $80 \%$ of these members being independent. This complies with the ASX recommendation that the board should establish a remuneration committee and that this should consist of a minimum of 3 (majority independent) directors and be chaired by an independent director.

The top 20 ASX listed companies recorded a 100\% independence score for their audit committees, whose average size was 4.50. The construction companies again differed with an average of 3.25 members, $92 \%$ of them being independent. This does, however, comply with the ASX guidelines that require the audit committee to be structured so that it consists of: only non-executive directors, a majority of independent directors, and an independent chairperson who is not chairperson of the board, and at least three members. Best practice would be only independent directors who are all financially literate, with at least one director with financial experience and one with industry knowledge.

\section{DISCUSSION}

The aim of this paper was to investigate the apparent relative compliance in annual reports of construction and non construction organisations listed on the ASX with the ASX CGC 'Principles of Good Governance and Best Practice Recommendations'. These were introduced in 2003, presenting a list of 30 recommendations for companies to achieve best practice in corporate governance. Compliance with these recommendations is a clear indication of an organisation's commitment to achieving best practice in corporate governance. In summary, it was found that, compared with the top 20 ASX listed companies, the Australian listed construction companies: (1) were less compliant with the ASX CGC principles and recommendations, particularly with regards to Principle 2, Structure of the Board; (2) had smaller boards with lower levels of independence both in terms of CEO-Chairperson duality and ratio of executive to non-executive independent directors; and (3) had less independent nomination, remuneration and audit committee membership.

Before discussing the implications of these results, it is worth reiterating that there is general acceptance that there is no single best board structure. Enforcing compliance requirements for board structure effectively removes the ability of an organisation to create a competitive advantage through developing what it considers to be its most effective board for its operating environment and business and it is not proposed to do that here. For example, organisational size and turnover is one of the key influences on size and structure of the board and committee composition and will therefore have influenced the differences discovered in this research between the two samples. This is because smaller companies do not face the same operational issues as larger ones and are less able to afford the costs of compliance than larger companies. This is relevant because the top 20 ASX listed non-construction companies in our sample were significantly larger (approximately six times) than the listed construction companies group in both employment numbers and turnover (see Table 5). While it could be argued that this makes comparison problematic, they are all subject to the same ASX guidelines, and comparison is valid with these limitations in mind.

In order to determine if there was a link between the size of the organisation and the size of the board in the two sample groups, the Spearman Rank Correlation test was performed using both measurements for organisational size in Table 2 (number of employees and turnover). The results indicated strong correlations in both cases ( 0.6664 for employees and 0.70863 for turnover).

Notwithstanding these qualifications, our results show that the Australian listed construction companies are less compliant with the ASX CGC principles and recommendations than the benchmark group of the top 20 ASX listed companies. This supports the findings of Chang et al. (2006) in the UK. The implications of these findings are important given that higher compliance is generally desirable, given these guidelines are designed to instil confidence in the international investment community about the monitoring of risk management and strategy: a critical issue in the recent credit constrained environment with uncertainties revolving around extreme market volatility. There is also evidence that lower compliance may also lead to poor organisational performance. For example, a recent study for the Association of British Insurers by Selvaggi and Upton (2008) found that companies with high compliance with the corporate

Table 5: Summary of sizes of the two sample groups

\begin{tabular}{|lll|}
\hline Group & Employment & Turnover \\
\hline Top 20 ASX & $\mathrm{n}=20$ & $\mathrm{n}=20$ \\
& Mean $=27,422$ & Mean $=\$ 17.48$ Billion \\
& $\mathrm{Sd}=37,589$ & $\mathrm{Sd}=\$ 14.8$ Billion \\
& Max $=180,000$ & Max $=\$ 47.47$ Billion \\
& Min $=1,241$ & Min $=\$ 3.27$ Billion \\
& & \\
Construction & $\mathrm{n}=17^{\star}$ & $\mathrm{n}=20$ \\
& Mean $=5,214$ & Mean $=\$ 2.37$ Billion \\
& $\mathrm{Sd}=8,795$ & $\mathrm{Sd}=\$ 3.93$ Billion \\
& Max $=30,000$ & Max $=\$ 14.28$ Billion \\
& Min $=34$ & Min $=\$ 0.053$ Billion \\
\hline *Three of the construction companies did not disclose their number of employees
\end{tabular}


governance codes exhibited higher returns (up to $18 \%$ higher) than those with lower compliance. The study also found that lower compliance led to lower intra-industry performance, higher volatility of share returns and lower chances of investment capital. There is also evidence that investors are willing to pay a premium for companies that demonstrate strong corporate governance credentials and that such companies tend to attract investors with a longer-term return horizon, thus promoting greater stability in stock prices, market value and greater resilience to the turbulence of market speculation (Coombes and Watson, 2000).

The implications of the smaller board size found in construction organisations are both positive and negative. While larger boards bring a wider variety of experience and knowledge, have greater resource availability and are less likely of being dominated by a CEO, their size if not managed well and can result in communication and coordination problems not encountered with smaller boards. In contrast, smaller boards can be dominated by a CEO, have less varied experience for identifying risks and trends, but can be more responsive and efficient in their decisionmaking.

The differences in the independence of the board are perhaps the most important finding. When independence is high, the board has a more objective and independent judgment and is more vigilant in monitoring, independent directors are less afraid to question the $\mathrm{CEO}$, and are more likely to fire an underperforming CEO (Bollard, 2003). When it is low, there is the risk of CEO domination, independent directors not having enough influence, and less vigilant monitoring of company performance. The higher incidence of CEO-Chair duality in construction companies means that there is less of a separation of ownership and control, and while there is no conclusive evidence to suggest that separating the roles results in a better organisational performance (Elsayed, 2007 ) it is widely argued that duality hinders the board's ability to perform its governance functions and leads to poorer monitoring of risks, particularly CEO performance (Rechner and Dalton, 1991).

The ratio of outside directors to inside directors is the other measure of a board's independence. Given that the sample of construction companies performed below the ASX top 20 benchmark, understanding the implication of this is important. In particular, Coles et al. (2008) found general consensus that a higher proportion of independent directors will result in more effective monitoring of the organisation or even improve the organisation's performance. The area of risk management in particular is widely regarded to be very important for construction companies which operate in a high risk environment. It is also an area of deficient performance in comparison to other highrisk industries (Loosemore et al., 2005). In this context, the idea of introducing a risk management committee (in addition to an audit committee), comprised of only independent directors, would increase board efficiency in risk oversight and control, help ensure the appropriateness and effectiveness of the risk management systems in place and instill confidence in investors about the effectiveness of the company's risk management strategies.

\section{CONCLUSION}

This research shows that construction companies could improve levels of independence on board subcommittees. The importance of independence differs for each committee. For example, the nomination committee needs independence to ensure that the right person with the right skill set is being elected to the board, rather than someone who is selected by the CEO to do as they are told. It will also help to ensure more transparent nomination and election processes, more effective board and director evaluations, and effective board succession planning. The remuneration committee is charged with determining appropriate levels of payment for the executive directors and independence helps to prevent excessive director remuneration packages, ensures appropriate performance incentives for directors, and enables shareholders to have confidence that their best interests are being maintained. Finally the audit committee is in place to ensure the protection of shareholders' interests in financial reporting. An independent audit committee safeguards the integrity of the company's financial reporting, ensuring accuracy of reporting and leading to greater investor confidence.

\section{REFERENCES}

ABS (2007) Construction, Australian Bureau of Statistics, http:// www.abs.gov.au/websitedbs/c311215.nsf/20564c23f3183fdaca2 5672100813ef1/fd50ade2f9b034c2ca256b60001d05fa!OpenDoc ument.

ACCA (2008) 'Climbing out of the credit crunch', Association of Chartered Certified Accountants, Policy Paper.

ASX (2003) Principles of Good Governance and Best Practice Recommendations First Edition, Sydney: Corporate Governance Council, ASX (available at http://www.shareholder.com/visitors/ dynamicdoc/document.cfm?documentid=364\&companyid=ASX).

Bollard, A. (2003) 'Corporate governance in the financial sector', Address, 7 April, The Annual Meeting of the Institute of Directors in New Zealand, Christchurch (available at http://www.rbnz.govt. nz/speeches/0132484.html).

Brancato, C K and Rabimov, S. (2008) The 2008 institutional investment report: trends in institutional investor assets and equity ownership of U.S. corporations, New York: The Conference Board, September, Report CB-1433.

Chang, C.Y., Chou, H.Y. and Wang, M. T. (2006) 'Characterizing the corporate governance of UK listed construction companies', Construction Management and Economics, 24(6), 647-656.

CLERP 9 (2004) Corporate Law Economic Reform Program (CLERP), Australian Securities and Investments Commission (available at http://www.asic.gov.au/asic/asic.nsf/byheadline/ CLERP+9?openDocument).

Colley, J., Doyle, J., Logan, G. and Stettinius, W. (2003) Corporate Governance, McGraw-Hill.

Coombes, P. and Watson, M. (2000) 'Three surveys on corporate governance, The McKinsey Quarterly, No. 4: Asia Revalued (available at http://www.qap.be/user_files/ITforBoards/GVCR_ McKinsey-Coombes_Paul_Watson_Mark_Three_surveys_on_corporate_governance_2000.pdf).

Coles, J., Naveen, D. and Naveen, L. (2008) 'Boards: does one size fit all?', Journal of Financial Economics, 87, 329-356.

Corporations Act (2001) available at http://www.austlii.edu.au/au/ legis/cth/consol_act/ca2001172/.

Davis, S., Lukomnik, J. and Pitt-Watson, D. (2006) The new capitalists: how citizen investors are reshaping the corporate agenda, Harvard Business School Press. 
Donker, H. and Zahir, S. (2008) 'Towards an impartial and effective corporate governance rating system', Corporate Governance, 8(1), 83-93.

du Plessis, J., McConvill, J. and Bagaric, M. (2005) Principles of contemporary corporate governance, Cambridge University Press.

Elsayed, K. (2007) 'Does CEO duality really affect corporate performance?', Corporate Governance, 15(6), 1203-1214.

Ingley, C. and van der Walt, N. (2003) 'Boards configuration: building better boards', Corporate Governance, 3(4), 5-17.

Khanchel, I. (2007) 'Corporate governance: measurement and determinant analysis', Managerial Auditing Journal, 22(8), 740760 .

Kiel, G. and Nicholson, G. (2003) Boards that work, McGraw-Hill.

Lawler III, E., Finegold, D., Benson, G. and Conger, J. (2002)

'Corporate boards: keys to effectiveness', Organizational Dynamics, 30(4), 310-324.

Loosemore, M., Raftery, J., Reilly, C. and Higgon, D. (2005) Risk management in projects, Taylor and Francis.

Mallin, C. (2006) Handbook on international corporate governance, Edward Elgar Publishing.

Martin, P. (2001) 'Ah, shareholders, let us be true to one another', Financial Times Online (available at http://www.ft.com/ cms/s/2/4570894c-6268-11da-8dad-0000779e2340,dwp_ uuid=574e8658-65ad-11da-8f40-0000779e2340.html).

Matheson, D. (2004) The complete guide to good governance in organizations and companies, Auckland: Profile Books.

Monks, R. and Mino, N. (2004) Corporate Governance, Third Edition, Blackwell Publishing.

Murphy, S. and McIntyre, M. (2007) 'Board of director performance: a group dynamics perspective', Corporate Governance, 7(2), 209-224.

Nadler, D. (2004) 'What's the board's role in strategy development?: engaging the board in corporate strategy', Strategy and Leadership, 32(5), 25-33.

NYSE (2008) New York Stock Exchange corporate governance (available at http://www.nyse.com/regulation/ nyse/1101074746736.html).

PPP Forum (2008) Projects Contracted (available at http://www. pppforum.gov.au/national_pipeline/projects_contracted).

Rechner, P. and Dalton, D. (1991) 'CEO duality and organizational performance: a longitudinal analysis', Strategic Management Journal, 12(2), 155-160.

Robins, F. (2006) 'Corporate governance after Sarbanes-Oxley: an Australian perspective', Corporate Governance, 6(1), 34-48.

Scherrer, P. (2003) 'Directors' responsibilities and participation in the strategic decision making process', Corporate Governance, $3(1), 86-90$.
Selvaggi, M. and Upton, J. (2008) Governance Performance in Corporate Britain, ABI Research Paper 7, London, Association of British Insurers (available at http://www.abi.org.uk/Members/ circulars/viewAttachment.asp?EID=18935\&DID=15815).

van Wyk, L. and Chege, L. (2004) 'Globalisation, corporate governance and the construction industry', in proceedings of International Symposium on Globalisation and Construction, 17 November, Bangkok.

van den Berghe, L. and Baelden, T. (2005) 'The complex relation between director independence and board effectiveness', Corporate Governance, 5(5), 58-83. 
